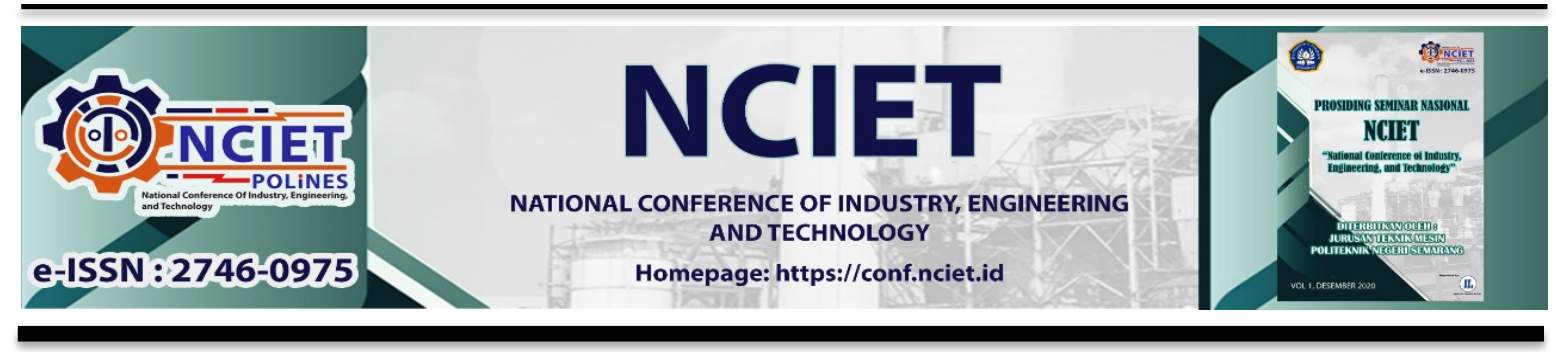

Prosiding Seminar Nasional NCIET Vol.1 (2020) B1-B12

$1^{\text {st }}$ National Conference of Industry, Engineering and Technology 2020, Semarang, Indonesia.

\title{
RANCANG BANGUN SUPLAI HYBRID ENERGY DENGAN AUTO SELECTION SWITCHING UNTUK BEBAN CHARGER BATTERY PADA LAPTOP DAN COOLING PAD
}

\author{
Brainvendra Widi Dionova ${ }^{1 *}$ Irianto $^{2}$ \\ ${ }^{1}$ Department of Electrical Engineering, Jakarta Global University \\ Jl. Boulevard Grand Depok City, Tirtajaya, Kec. Sukmajaya, Depok, 16412 \\ ${ }^{2}$ Department of Electical Engineering, Politeknik Elektronika Negeri Surabaya \\ Kampus ITS, Jl. Raya ITS, Keputih, Kec. Sukolilo, Surabaya, 60111 \\ *E-mail: Brainvendra@jgu.ac.id
}

\begin{abstract}
Abstrak
Dengan meningkatnya kebutuhan energi listrik tiap tahunnya akan menimbulkan permasalahan dalam penyediaannya. Oleh karena itu, penelitian ini bertujuan untuk membuat sistem untuk memaksimalkan pemanfaatan energy listrik dari panel surya pada sumber energi hybrid yang berasal dari panel surya dan PLN. Energi hybrid ini digunakan untuk mensuplai beban charger dan cooling pad laptop. Sumber energi daripanel surya digunakan untuk charging baterai atau suplai ke beban langsung yaitu 200WP. Pada charging baterai menggunakan boost converter untuk mengisi baterai $24 \mathrm{~V}$ dengan kapasitas $32 \mathrm{Ah}$ yang memiliki tegangan charging $28.9 \mathrm{~V}$ dengan nilai arus keluaran 2.4A. Pada suplai beban langsung menggunakan boost converter yang memiliki tegangan 20.009V dengan nilai arus keluaran 3.684A. Sumber energi dari PLN dapat digunakan untuk sewaktu-waktu apabila panel tidak dapat digunakan atau sedang digunakan untuk charging dari PLN untuk mensuplai beban langsung dengan tegangan keluaran $20.42 \mathrm{~V}$ dengan menggunakan AC-DC fullwave uncontrolled rectifier. Sumber energi dari baterai digunakan untuk suplai beban dengan tegangan keluaran. Pada penelitian ini menggunakan mikrokontroler untuk mengatur saklar (relay) yang mampu memutus dan menggati suumber yang digunakan untuk mensuplai sistem. Serta menggunakan kontrol PID pada boost converter untuk mengatur duty cycle supaya tegangan keluaran konstan.
\end{abstract}

Kata Kunci: Suplai Hybrid; Solar cell; DC-DC; Converter; Boost converter 


\section{PENDAHULUAN}

Kebutuhan energi listrik terus meningkat tiap tahunnya karena pertambahan penduduk dan pertumbuhan ekonomi yang meningkat.Untuk menopang penyediaan energi listrik di Indonesia, bahan bakar fosil masih merupakan sumber utama hingga saat ini (Vibhute \& Shukla, 2017). Bahan bakar fosil semakin menipis dan persediaanya terbatas. Bahkan bila diasumsikan tidak ada penemuan cadangan baru maka persediaan minyak bumi akan habis dalam 13 tahun, gas bumi 34 tahun, dan batu bara 72 tahun. Untuk itulah perlu dioptimalkan pemanfaatan Energi baru terbarukan (Hendrawati et al., 2017). Biaya awal energi terbarukan yang lebih tinggi dibandingkan teknologi energi konvensional sering dipandang sebagai kendala dalam pengembangan energi terbarukan (Hendrawati et al., 2019)

Sejalan dengan meningkatnya pemanfaatan solar cell dalam penyediaan energi listrik alternatif, penelitian ini juga membahas pemanfaatan solar cell untuk mensuplai beban listrik DC ataupun untuk disimpan dalam baterai. Penelitian ini tetap menggunakan suplai listrik dari PLN untuk menjamin tetap tersedianya suplai energi ke beban, sehingga sumberenergi pada tugas akhir ini menggunakan suplai hybrid (dua sumber). Kendala pemanfaatan solar cell adalah besarnya keluaran yang tidak stabil, yang dapat merusak beban. Untuk mengatasinya, dibutuhkan rangkaian kontrol yang dapat menghasilkan keluaran yang stabil. Kontrol duty cyle PWM pada converter terbukti dapat menjaga kestabilan tegangan (Dionova et al., 2020; Hendrawati et al., 2015; Rakhmawati et al., 2017).

Penggunaan suplai hybrid pada penelitian ini ditujukan untuk meminimalkan penggunaan suplai dari PLN atau memaksimalkan suplai energi dari solar cell yang dilengkapi dengan penyimpan energi (baterai). Untuk mengatur kerja suplay hybrid termasuk baterai dan kestabilan tegangan untuk kedua beban tersebut dibutuhkan mikrokontroller, khususnya dalam mengatur duty cycle kedua konverter agar tujuan kinerja sistem tercapai. Mikrokontroler ini digunakan untuk membaca keluaran tegangan dan arus converter melalui ADC, dan sangat dibutuhkan untuk membangun sistem suplai hybrid (dan baterai) untuk kedua beban dengan batasan-batasan yang ditentukan. Batasan untuk suplai energi yaitu sumber energi dari PLN hanya menjadi sumber emergency yang digunakan apabila solar cell tidak dapat menghasilkan daya dan baterai dalam keadaan low. Sedangkan batasan pada beban adalah diterimanya tegangan yang stabil dan daya sesuai spesifikasi. 


\section{METODE PENELITIAN}

Perancangan dan pembutan penelitian ini berpatokan pada blok diagram sistem serta alur kerja dari blok diagram. Berikut merupakan gambaran umum sistem yang ditunjukan pada Gambar 1.

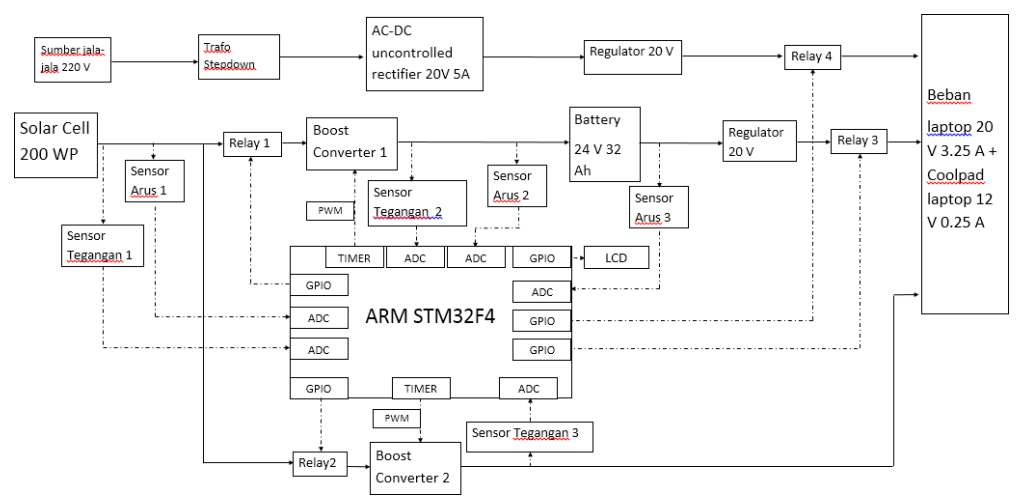

Gambar 1. Blok Diagram Sistem

1. Perencanaan Kebutuhan Daya Panel Surya

Penggunaan daya dari panel surya yang paling besar adalah untuk charging baterai.

Baterai yang digunakan adalah 24 Volt 32 Ah dengan parameter charging yaitu

$: \mathrm{Vch}=28.8$ Volt

$\mathrm{Ich}=6 \mathrm{~A}$ (desain maksimum)

$t=\frac{A h}{I c h}$

$t=\frac{32}{6}$

$t=5.3$ hour

Sedangakan energi yang dibutuhkan untuk charging baterai adalah

$:$ Wout $=$ Vch $\times$ Ich $\times \mathrm{t}$

$$
\begin{aligned}
& =28.8 \times 6 \times 5.3 \\
& =915.84 \mathrm{Wh}
\end{aligned}
$$

Jika menggunakan panel surya 200 WP dan diasumsikan panel surya setiap harinya dapat menghasilkan daya sekitar 4-5 hour dalam keadaan cerah maka energi yang dapat dihasilkan:

$$
\begin{aligned}
\text { Win } & =\mathrm{P}(\text { peak }) \times \mathrm{h} \\
& =200 \times 5 \\
& =1000 \mathrm{Wh}
\end{aligned}
$$

Maka pada penelitian ini menggunakan panel surya 100WP sebanyak 2 buah yang dipasang secara paralel. 


\section{Perencanaan dan Pembuatan $A C$-DC Fullwave Uncontrolled Rectifier}

Pada penelitian ini menggunakan AC-DC Full-Wave Uncontrolled Rectifier sebagai suplai beban. Perencanaan power suplai untuk beban ini menggunakan rangkaian AC-DC Full-Wave Uncontrolled Rectifier dengan filter C dan adjustable voltage regulator IC 317 yang diberi rangkaian pass transistor dapat dilihat pada Gambar 2. Tabel 1 menunjukkan spesifikasi tegangan input dan tegangan output yang digunakan didalam rangkaian $A C-D C$ Fullwave Uncontrolled Rectifier.

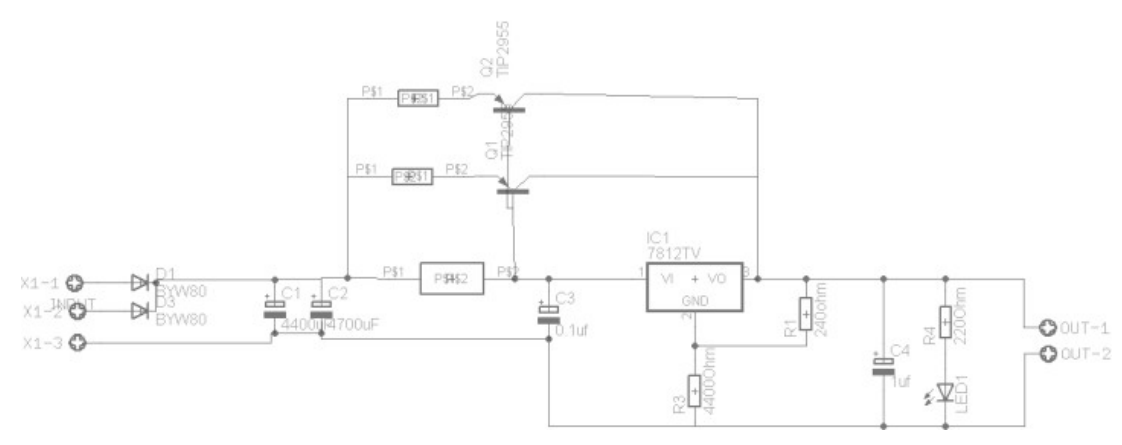

Gambar 2. Rangkaian AC-DC Fullwave Uncontrolled Rectifier + regulator ic 713

Tabel 1. Spesifikasi Rangkaian AC-DC Fullwave Uncontrolled Rectifier

\begin{tabular}{|c|c|}
\hline $\mathrm{Vs}$ & $20 \mathrm{VAC}$ \\
\hline $\mathrm{Vo}$ & $28.28 \mathrm{~V}$ \\
\hline$\Delta \mathrm{Vo}$ & $4.655 \mathrm{~V}$ \\
\hline $\mathrm{Vo}_{(\mathrm{dc})}$ & 25.95 \\
\hline
\end{tabular}

Dari perhitungan diatas keluaran dari rangkaian AC-DC fullwave uncontrolled rectifier adalah 25.95V. Dibutuhkan IC 713 untuk menstabilkan tegangan menjadi 20V dengan melakukan pengaturan pada nilai resistornya. Apabila menggunakan resistor bernilai $3.3 \mathrm{k} \Omega$ maka :

$$
\begin{aligned}
\operatorname{Vo} & =\operatorname{Vref}\left(1+\frac{R 2}{R 1}\right) \\
\operatorname{Vo} & =\operatorname{Vref}\left(1+\frac{3300}{220}\right) \\
& =20 \mathrm{~V}
\end{aligned}
$$

Sedangkan rangkaian pass transistor digunakan untuk penguat arus, karena batas maksimal arus pada IC LM713 hanya 1.5A dan kebutuhan arus keluaran adalah 3.5A maka rangkaian pass transistor akan melewatkan arus lenih menuju ke output. 
3. Perancangan dan pembuatan Regulator

Pada penelitian ini menggunakan Regulator dengan dioda zener sebagai penstabil tegangan dari baterai ke beban. Rangkaian regulator ini menggunakan dioda zener dan rangkaian pass transistor untuk sebagai penguat arus yang dapat dilihat pada Gambar 3 .

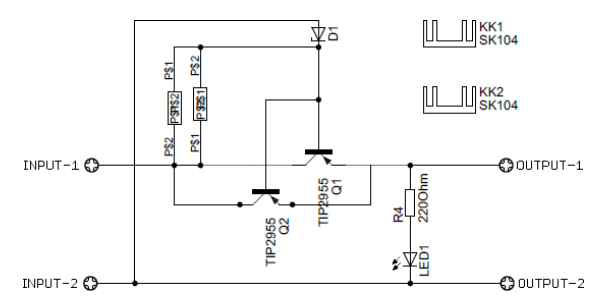

Gambar 3. Rangkaian regulator menggunakan dioda zener

\section{Perencanaan dan Pembuatan Boost Converter}

Boost converter adalah rangkaian elektronik yang digunakan untuk mengkonversi file tegangan tak terkendali dc menjadi tegangan terkontrol dc, dan memang demikian disebut boost converter karena tegangan output dc adalah lebih besar dari tegangan input dc. Gambar 5. Dorongan hadir sirkuit konverter. Ada dua seri analisis dorongan konverter di sakelar (mosfet) hidup dan mati. Saat beralih (mosfet) ditutup, dioda bias penghormatan, dalam status kirchhoff sehingga arus induktor meningkat secara linier. Saat sakelar (mosfet) dibuka, dioda mengarah ke depan bias untuk menyediakan jalur arus induktor.

a. Boost Converter 1

Boost Converter 1 digunakan untuk menaikan tegangan dari panel surya yang digunakan untuk proses charging baterai dapat dilihat pada Gambar 4. Sedangkan spesifikasi komponen pada boost converter 1 dapat dilihat pada table 2.

Perhitungan Vcharging $\quad=2.4 \times 6 \times 2 \quad=28.8 \mathrm{~V}$

(2.4 untuk satu cell baterai, 2 untuk penggunaan 2 baterai

) Perhitungan Icharging $\quad=18.75 \% \times 32=6 \mathrm{~A}$

Pout converter $=28.8 \times 6=172.8 \mathrm{~W}$

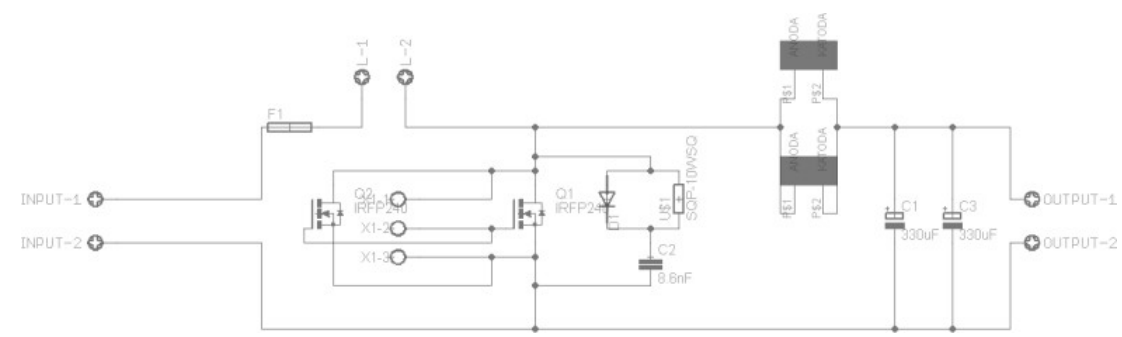

Gambar 4. Rangkaian boost converter 1 
Tabel 2. Spesifikasi yang digunakan pada Boost Converter 1

\section{b. Boost Converter 2}

\begin{tabular}{|c|c|c|c|c|c|}
\hline $\mathrm{f}$ & Vin & Vout & $\mathrm{L}$ & $\mathrm{C}$ & $\mathrm{R}$ \\
\hline $40 \mathrm{KHz}$ & $12 \mathrm{~V}$ & $28.8 \mathrm{~V}$ & $63.17 \mathrm{uH}$ & $607.29 \mathrm{uH}$ & $4.8 \Omega$ \\
\hline
\end{tabular}

Boost Converter 2 digunakan untuk menaikan tegangan dari panel surya yang digunakan untuk proses suplai beban dapat dilihat pada Gambar 5. Sedangkan spesifikasi komponen pada boost converter 1 dapat dilihat pada table 3 .

$\begin{array}{ll}\text { Vout } & =20 \mathrm{~V} \\ \text { Iout } & =3.5 \mathrm{~A}\end{array}$

Pout converter $=20 \times 3.5=70 \mathrm{~W}$

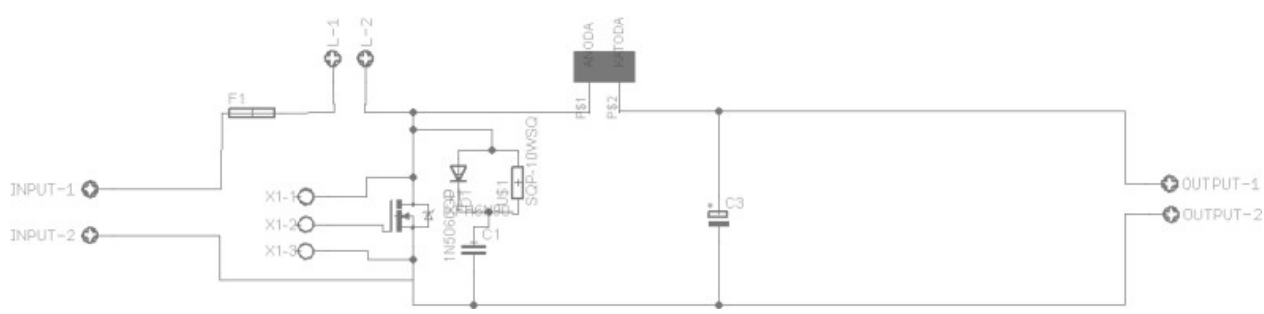

Gambar 5. Rangkaian boost converter 2

Tabel 3. Spesifikasi yang digunakan pada Boost Converter 1

5. Perancangan kontrol PID pada boost converter

\begin{tabular}{|c|c|c|c|c|c|}
\hline $\mathrm{f}$ & Vin & Vout & $\mathrm{L}$ & $\mathrm{C}$ & $\mathrm{R}$ \\
\hline $40 \mathrm{KHz}$ & $12 \mathrm{~V}$ & $28.8 \mathrm{~V}$ & $63.17 \mathrm{uH}$ & $607.29 \mathrm{uH}$ & $4.8 \Omega$ \\
\hline
\end{tabular}

Kontrol PID yang digunakan berfungsi untuk mengatur nilai duty cycle supaya keluaran dari boost converter dapat menghasilkan tegangan keluaran yang konstan dari input panel surya yang berubah-ubah. Yang diinginkan dari kontrol ini dapat mendapatkan rise time dan settling time yang cepat dan tidak terdapat osilasi. Tabel 4 adalah tanggapan sistem apabila diberi kontrol PID.

Tabel 4. Tanggapan sistem kontrol PID

\begin{tabular}{|l|l|l|}
\hline $\begin{array}{l}\text { Tanggapan Loop } \\
\text { Tertutup }\end{array}$ & Waktu Naik & Overshoot \\
\hline Proporsional (Kp) & Menurun & Meningkat \\
\hline Integral (Ki) & Menurun & Meningkat \\
\hline Derivative (Kd) & $\begin{array}{l}\text { Perubahan } \\
\text { kecil }\end{array}$ & Menurun \\
\hline
\end{tabular}




\begin{tabular}{|l|l|l|}
\hline $\begin{array}{l}\text { Tanggapan Loop } \\
\text { Tertutup }\end{array}$ & Waktu turun & $\begin{array}{l}\text { Kesalahan } \\
\text { Keadaan tunak }\end{array}$ \\
\hline roporsional $(\mathrm{Kp})$ & $\begin{array}{l}\text { Perubahan } \\
\text { kecil }\end{array}$ & Menurun \\
\hline Integral (Ki) & Meningkat & Hilang \\
\hline Derivative (Kd) & $\begin{array}{l}\text { Perubahan } \\
\text { kecil }\end{array}$ & Menurun \\
\hline
\end{tabular}

\section{HASIL DAN PEMBAHASAN}

Dalam pembahasan ini akan dipaparkan hasil pengujian partial yang telah dilakukan.

\section{Pengujian Karakteristik Panel Surya}

Pengujian solar panel bertujuan agar diperoleh karakteristik dari panel surya yang mana hasil dari pengujian karakteristik panel surya agar dapat diketahui daya maksimum dan daya tiap jam dapat dilihat pada Gambar 6. Menunjukan hasil pengujian. Dari Gambar kurva 7 dilihat bahwa arus maksimum yang dimiliki solar cell adalah 10.95 Ampere dan tegangannya 19.6 Volt. Nilai tegangan dan daya yang dimiliki solar cell berubah-ubah tergantung dari radiasi sinar matahari.

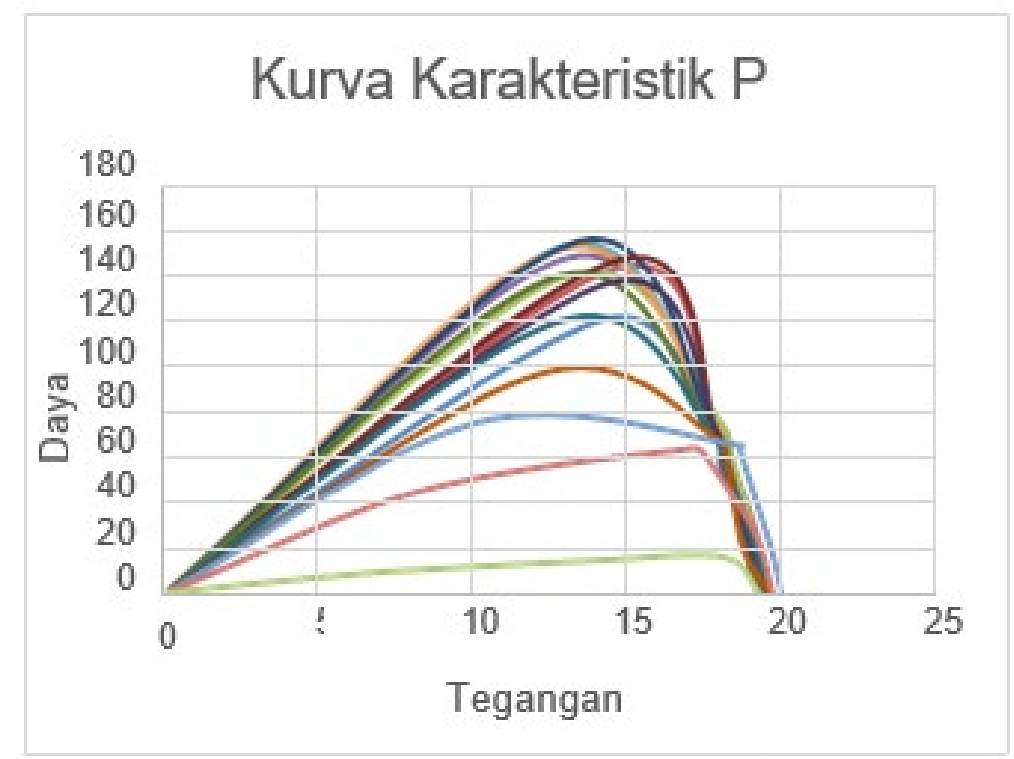

Gambar 6. Karakteristik P-V panel surya 200WP 


\section{Kurva Karakteristik V - I}

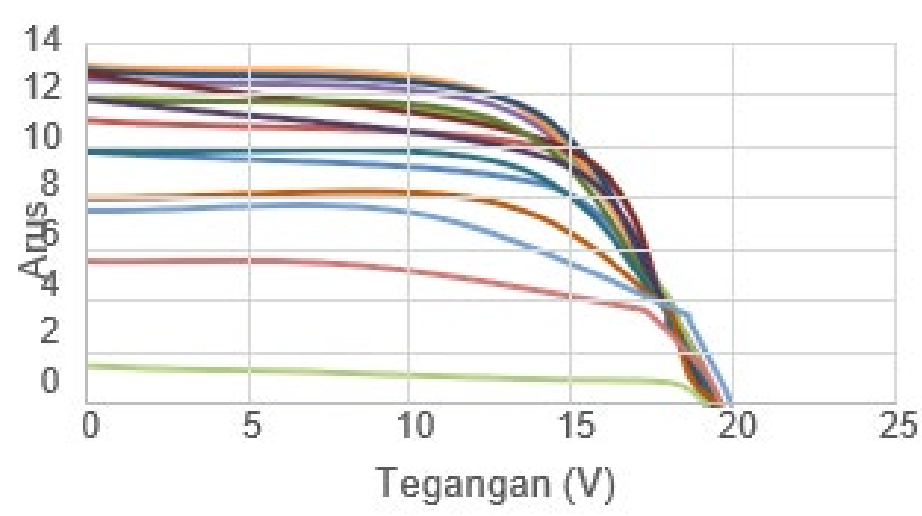

Gambar 7. Karakteristik V-I panel surya 200WP

\section{Pengujian AC-DC Fullwave Uncotrolled Rectifier}

Gambar 8 adalah hardware dari rangkaian AC-DC fullwave uncontrolled rectifier dan regulator dengan IC LM317. Pada keluaran AC-DC fullwave uncontrolled rectifier menghasilkan tegangan keluaran 20.24V 3.8A yang dapat digunakan sewaktu-waktu sebagai cadangan sumber energi.

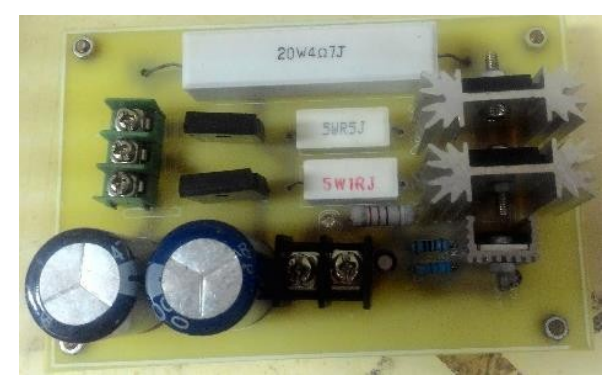

Gambar 8. Rangkaian AC-DC Fullwave Uncontrolled Rectifier

3. Pengujian regulator

Gambar 5 adalah hardware dari rangkaian regulator dioda zener dengan transistor daya. Pada keluaran regulator menghasilkan tegangan keluaran $20.03 \mathrm{~V} 3.8 \mathrm{~A}$ yang dapat digunakan apabila baterai tidak dalam keadaan low.

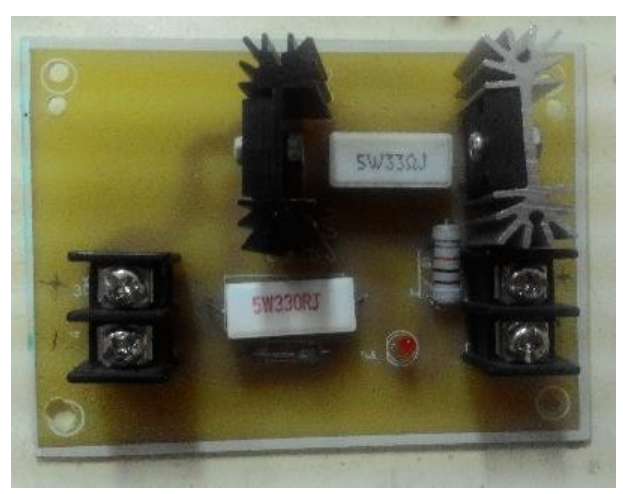

Gambar 9. Rangkaian regulator 


\section{Pengujian Boost Converter}

a. Pengujian Boost converter 1

Boost converter 1 digunakan untuk charging baterai dari sumber panel surya yang tegangannya berubah-ubah. Untuk mendapatkan tegangan keluaran yang konstan dibutuhkan suatu kontrol yaitu kontrol PID untuk merubah duty cycle agar nilai tegangan keluaran yang diharapkan sesuai desain. Gambar 10 adalah pengujian dari boost converter 1. Tabel 2 menunjukan hasil pengujian boost converter 1 dengan kontrol PID agar tegangan keluaran stabil $28.8 \mathrm{~V}$. Pengujian dapat dikatakann berhasil dikarenakan arus charging pada baterai turun dan mendekati full charge.

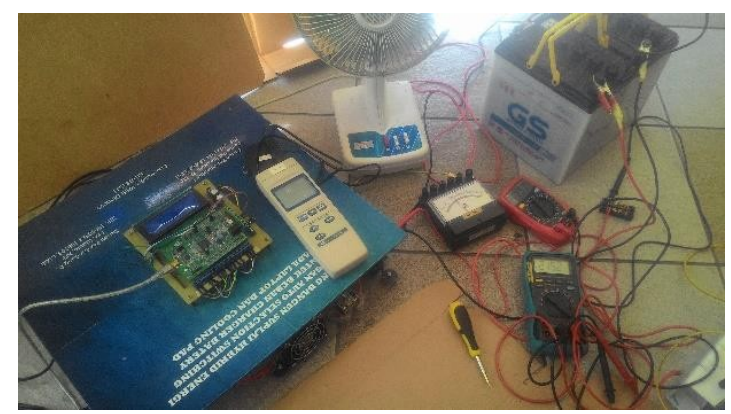

Gambar 10. Pengujian boost converter 1

Tabel 5. Pengujian boost converter 1 dengan kontrol PID

\begin{tabular}{|l|l|l|l|l|l|}
\hline waktu & Duty & $\begin{array}{l}\text { Vin } \\
(\mathrm{V})\end{array}$ & $\begin{array}{l}\text { Iin } \\
(\mathrm{A})\end{array}$ & $\begin{array}{l}\text { Vo(p) } \\
(\mathrm{V})\end{array}$ & $\begin{array}{l}\text { Io } \\
(\mathrm{A})\end{array}$ \\
\hline $10: 30: 00$ & 631 & 11.01 & 11 & 28.56 & 2.4 \\
\hline $10: 40: 00$ & 554 & 9.8 & 11 & 28.93 & 2.07 \\
\hline $10: 50: 00$ & 492 & 9 & 11.4 & 28.98 & 1.83 \\
\hline $11: 00: 00$ & 440 & 8.15 & 11.5 & 28.88 & 1.62 \\
\hline $11: 10: 00$ & 434 & 8.14 & 11.5 & 28.99 & 1.56 \\
\hline $11: 20: 00$ & 424 & 8.03 & 11.5 & 28.98 & 1.51 \\
\hline $11: 30: 00$ & 389 & 7.58 & 11.8 & 28.86 & 1.44 \\
\hline $11: 40: 00$ & 383 & 7.5 & 12 & 28.88 & 1.42 \\
\hline $11: 50: 00$ & 391 & 7.6 & 11.9 & 28.94 & 1.4 \\
\hline $12: 00: 00$ & 426 & 7.85 & 11.5 & 29.08 & 1.39 \\
\hline $12: 10: 00$ & 407 & 7.8 & 11.55 & 28.91 & 1.37 \\
\hline $12: 20: 00$ & 391 & 7.6 & 11.8 & 28.93 & 1.36 \\
\hline $12: 30: 00$ & 399 & 7.73 & 11.6 & 28.92 & 1.33 \\
\hline
\end{tabular}




\section{b. Pengujian Boost converter 2}

\begin{tabular}{|l|l|l|l|l|l|}
\hline waktu & Duty & $\begin{array}{l}\text { Vin } \\
\text { (V) }\end{array}$ & $\begin{array}{l}\text { Iin } \\
\text { (A) }\end{array}$ & $\begin{array}{l}\text { Vo(p) } \\
\text { (V) }\end{array}$ & $\begin{array}{l}\text { Io } \\
\text { (A) }\end{array}$ \\
\hline 12:40:00 & 402 & 7.75 & 11.6 & 28.89 & 1.31 \\
\hline 12:50:00 & 404 & 7.67 & 11.4 & 28.94 & 1.29 \\
\hline 13:00:00 & 385 & 7.3 & 11.3 & 28.84 & 1.27 \\
\hline
\end{tabular}

Boost converter 2 digunakan untuk suplai beban langsung dari sumber panel surya yang tegangannya berubah-ubah. Untuk mendapatkan tegangan keluaran yang konstan dibutuhkan suatu kontrol yaitu kontrol PID untuk merubah duty cycle agar nilai tegangan keluaran yang diharapkan sesuai desain. Gambar 11 adalah pengujian dari boost converter 2. Tabel 6 menunjukan hasil pengujian boost converter 2 dengan kontrol PID agar tegangan keluaran stabil 20V. Pengujian diatas dapat dilihat bahwa apabila menggunakan panel surya dan ingin mensuplai beban langsung dapat digunakan dari mulai pukul 08:30 sampai 15:30.

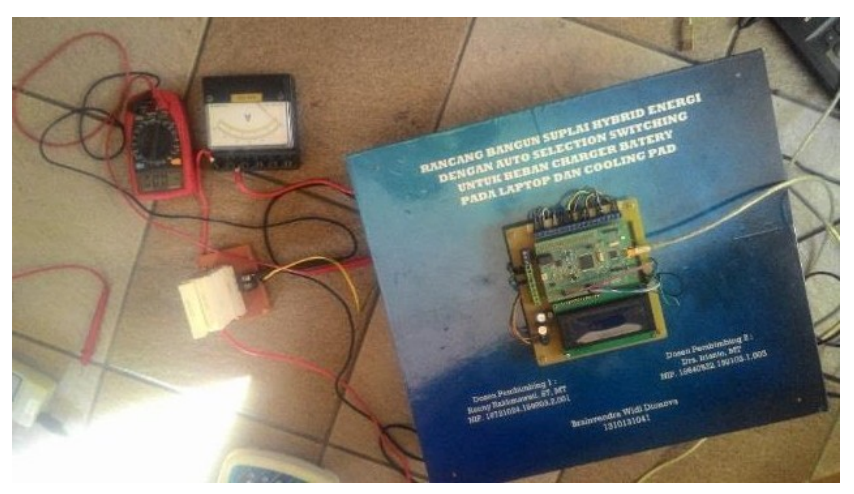

Gambar 11. Pengujian boost converter 2

Tabel 6. Pengujian boost converter 2 dengan kontrol PID

\begin{tabular}{|l|l|l|l|l|l|}
\hline waktu & Duty & $\begin{array}{l}\text { Vin } \\
(\mathrm{V})\end{array}$ & $\begin{array}{l}\text { Iin } \\
\text { (A) }\end{array}$ & $\begin{array}{l}\text { Vo(p) } \\
(\mathrm{V})\end{array}$ & $\begin{array}{l}\text { Io } \\
(\mathrm{A})\end{array}$ \\
\hline $8: 30$ & 729 & 16.45 & 5.8 & 19.99 & 3.68 \\
\hline $9: 00$ & 685 & 16.8 & 5.6 & 20.09 & 3.71 \\
\hline $9: 30$ & 712 & 16.61 & 5.75 & 20.02 & 3.69 \\
\hline $10: 00$ & 709 & 16.6 & 5.7 & 20.04 & 3.68 \\
\hline $10: 30$ & 721 & 16.53 & 5.8 & 20.06 & 3.69 \\
\hline $11: 00$ & 736 & 16.4 & 5.8 & 20.04 & 3.69 \\
\hline
\end{tabular}




\begin{tabular}{|l|l|l|l|l|l|}
\hline waktu & Duty & (V) & $\begin{array}{l}\text { Iin } \\
(\mathrm{A})\end{array}$ & $\begin{array}{l}\text { Vo(p) } \\
(\mathrm{V})\end{array}$ & $\begin{array}{l}\text { Io } \\
(\mathrm{A})\end{array}$ \\
\hline $11: 30$ & 727 & 16.5 & 5.75 & 20.02 & 3.68 \\
\hline $12: 00$ & 729 & 16.4 & 5.8 & 19.97 & 3.68 \\
\hline $12: 30$ & 713 & 16.5 & 5.8 & 20.04 & 3.69 \\
\hline $13: 00$ & 707 & 16.5 & 5.7 & 19.98 & 3.68 \\
\hline $13: 30$ & 701 & 16.6 & 5.7 & 20.02 & 3.69 \\
\hline $14: 00$ & 751 & 16.2 & 5.9 & 20.03 & 3.69 \\
\hline $14: 30$ & 783 & 16 & 6 & 20 & 3.68 \\
\hline $15: 00$ & 716 & 16.7 & 5.7 & 19.94 & 3.66 \\
\hline $15: 30$ & 784 & 16.1 & 6 & 19.9 & 3.67 \\
\hline
\end{tabular}

\section{KESIMPULAN}

Setelah dilakukan proses studi literatur, perencanaan dan pengujian, pengambilan data dan analisa data serta membandingkan dengan teori teori penunjang, maka dapat disimpulkan bahwa :

1. Sumber energi listrik dari PLN dapat digunakan sewaktu-waktu untuk cadangan sumber energi listrik menggunakan AC-DC fullwave uncontrolled rectifier sebesar $20.24 \mathrm{~V}$ 3.8A.

2. Sumber energi listrik dari panel surya dapat digunakan untuk charging baterai atau suplai kebeban langsung. Untuk charging baterai tegangan dan arus keluaran boost converter 1 sebesar $28.56 \mathrm{~V} 2.4 \mathrm{~A}$ dan baterai dalam keadaan terisi sebagian. Untuk suplai beban langsung tegangan dan arus keluaran boost converter 2 sebesar 19.98V 3.68A dan dapat digunakan dari pukul 08:30 sampai 15:30.

3. Sumber energi listrik dari baterai dapat digunakan apabila baterai sudah dalam keadaan full menggunakan regulator sebesar 20.03V 3.8A.

4. Keempat sistem tersebut dapat digunakan secara bergantian untuk mensuplai beban dengan menggunakan pemutus (saklar) secara otomatis yaitu relay yang dikontrol oleh mikrokontroler.

5. Beban yang digunakan adalah beban resistor balok putih yang diasumsikan laptop dan cooling pad yang disesuaikan pada kebutuhan daya keluaran. 


\section{DAFTAR PUSTAKA}

Dionova, B. W., Mohammed, M. N., Al-Zubaidi, S., \& Yusuf, E. (2020). Environment indoor air quality assessment using fuzzy inference system. ICT Express, 6(3), 185194. https://doi.org/10.1016/j.icte.2020.05.007

Hendrawati, D., Soeprijanto, A., \& Ashari, M. (2017). High performance maximum power point tracking on wind energy conversion system. International Journal of Power Electronics and Drive Systems, 8(3), 1359-1367. https://doi.org/10.11591/ijpeds.v8i3.pp1359-1367

Hendrawati, D., Soeprijanto, A., \& Ashari, M. (2019). Turbine wind placement with staggered layout as a strategy to maximize annual energy production in onshore wind farms. International Journal of Energy Economics and Policy, 9(2), 334-340. https://doi.org/10.32479/ijeep.7437

Hendrawati, D., Soeprijanto, A., \& Ashari, M. (2015). Optimal Power and Cost on Placement of Wind Turbines using Firefly Algorithm. 2015 International Conference on Suistainable Energy Engineering and Application, 59-64.

Rakhmawati, R., Irianto, \& Dionova, B. W. (2017). Design and implementation of hybrid energy system for DC load applications. Proceedings - 2017 International Seminar on Application for Technology of Information and Communication: Empowering Technology for a Better Human Life, ISemantic 2017, 2018-Janua, 109-114. https://doi.org/10.1109/ISEMANTIC.2017.8251853

Vibhute, K., \& Shukla, R. (2017). All weather solar cell- A new trend of design of solar cell. International Conference on Electrical Power and Energy Systems, ICEPES 2016, 133 138. https://doi.org/10.1109/ICEPES.2016.79 